\title{
Effects of Cadmium on the Contractility of a Frog Cardiac Muscle in Relation to $\mathrm{pH}$ of External Solution
}

\author{
Etsuko HoRIUCHI and Hideo HAYASHI \\ Department of Physiology, Saitama Medical School, \\ Moroyama, Iruma-gun, Saitama, 350-04 Japan
}

\begin{abstract}
In order to examine the $\mathrm{pH}$ dependency of $\mathrm{Cd}$ effects on cardiac muscle, the electrical and mechanical activities in the bullfrog heart were investigated in relation to various external $\mathrm{pHs}$ and concentrations of $\mathrm{Cd}$. The amplitude and duration of the action potential or the spontaneously beating frequency in the atrium were not significantly affected during the 3-min administration of various concentrations of $\mathrm{Cd}$ in a range from $\mathrm{pH} 6$ to 10 , but the isotonic contraction at the end of the same period was greatly altered: the lower the external $\mathrm{pH}$ the more $\mathrm{Cd}$ decreased the contractility of the atrium. This $\mathrm{pH}$ dependency of $\mathrm{Cd}$ effects was also observed in $\mathrm{SO}_{4}$-Ringer's solution whose anions, $\mathrm{SO}_{4}$, were more impermeable than $\mathrm{Cl}$. Decrease in contractility in $\mathrm{Cd}$ Ringer's solution was counteracted by excess $\mathrm{Ca}$. The lower the $\mathrm{pH}$ of the Cd-Ringer's solution, the more $\mathrm{Ca}$ was necessary to counteract an equal amount of $\mathrm{Cd}$. The amount of Cd-uptake into the atrium was analyzed after soaking the atrium in various concentrations of Cd-Ringer's solution. The higher the concentration of external Cd, the larger the $\mathrm{Cd}$-uptake into the atrium. No $\mathrm{pH}$ dependency, however, was observed in this relationship. This suggests that probably only a small fraction of total Cd-uptake interacts with Ca-binding sites which is specific to contraction, and causes the Cd-induced decrease in contractility. This process is considered to be $\mathrm{pH}$-dependent. However, most Cd-uptake into cardiac muscle is $\mathrm{pH}$-independent and may be nonspecific to contraction.
\end{abstract}

Effects of cadmium (Cd) on the electrical and mechanical activities of cardiac muscle in normal pH solution have been studied (KLEINFELD et al., 1955; TAKahashi et al., 1956; Kleinfeld and Stein, 1968; Hayashi and Horiuchi, 1971a; TodA, 1973). It was found that a low concentration of $\mathrm{Cd}$ (about $10 \mu \mathrm{M})$ brought about a decrease in contractility without an appreciable change in the action potential, and this $\mathrm{Cd}$ effect on contractility was completely antagonized by excess Ca (HAYASHI and HORIUCHI, 1971a). It was also reported

Received for publication March 9, 1979

堀内隑子, 林 秀生 
that, when the $\mathrm{pH}$ of the medium was changed, the amount of bound $\mathrm{Ca}$ in isolated sarcolemma or sarcoplasmic reticulum, which is closely related to contraction, was changed (NAKamaru and Schwartz, 1970; Williamson et al., 1975). Based on these facts, it was postulated that $\mathrm{Cd}$ which counteracted $\mathrm{Ca}$ might also exert $\mathrm{pH}$ dependency; i.e., the lower the external $\mathrm{pH}$ of the Ringer's solution, the more enhanced the $\mathrm{Cd}$ effects. The everted sinus-atrium preparation of a bullfrog was used to test this assumption. Recording of intracellular potential of the excised atrium was made to confirm the results obtained from the sinusatrium preparation.

Finally, the relation between the amount of Cd-uptake and the contractility was discussed in relation to the external $\mathrm{pH}$.

A preliminary account of this work has been published elsewhere (HoRIUCHI and HAYASHI, 1978).

\section{MATERIALS AND METHODS}

The everted sinus-atrium preparations of bullfrogs (Rana catesbeiana) of either sex were used. The frogs were anesthetized by an intrathecal injection of $0.5 \mathrm{ml}$ urethane solution $(0.25 \mathrm{~g} / \mathrm{ml})$. The heart was excised together with its blood vessels which were ligated and sectioned proximal to the heart. The greater part of the ventricle was removed by cutting out about $2 \mathrm{~mm}$ below the atrio-ventricular groove. The remaining heart (atrium with sinus) kept beating in an almost normal rhythm. After washing out the blood in the heart, most of the septum in the atrium was removed with great care. The sinusatrium preparation was reversed inside out by a puff of Ringer's solution from a pipette. This everted sinus-atrium preparation was fixed tightly at the tip (3.3 $\mathrm{mm}$ in inner diameter) of a cannula $(30.0 \mathrm{~mm}$ in inner diameter) with a piece of thread, and was immersed in Ringer's solution of various $\mathrm{pHs}(30 \mathrm{ml})$. Normal Ringer's solution of $\mathrm{pH} 7.2$ was put into the cannula, and the inside pressure was $1 \mathrm{cmH}_{2} \mathrm{O}$ higher than that outside. The epicardium of the atrium was much thicker than the endocardium (HoRIUCHI and HAYASHI, 1973); therefore the everted sinus-atrium preparation may allow a quick access and wash-out of drugs by exchanging the outside solution (HAYASHI and HoRIUCHI, 1971b). Figure 1 illustrates the schematic diagram for simultaneous recording of mechanical and electrical events of the preparation. The contraction of the preparation was transformed into a small change in pressure, and recorded with a high sensitivity pressure transducer (Nihon Kohden LPU-0.1), a carrier amplifier (AP-300 G), and a pen writer (PMP-3004). The electrical events were recorded by a suction electrode ( $200 \mu \mathrm{m}$ inner tip diameter) and an amplifier of a high input impedance (AB-300 G; ARITA and HAYASHI, 1973). In order to confirm the findings by using suction electrodes, we recorded intracellular membrane potentials by a conventional method (microelectrodes of more than $20 \mathrm{M} \Omega$ 


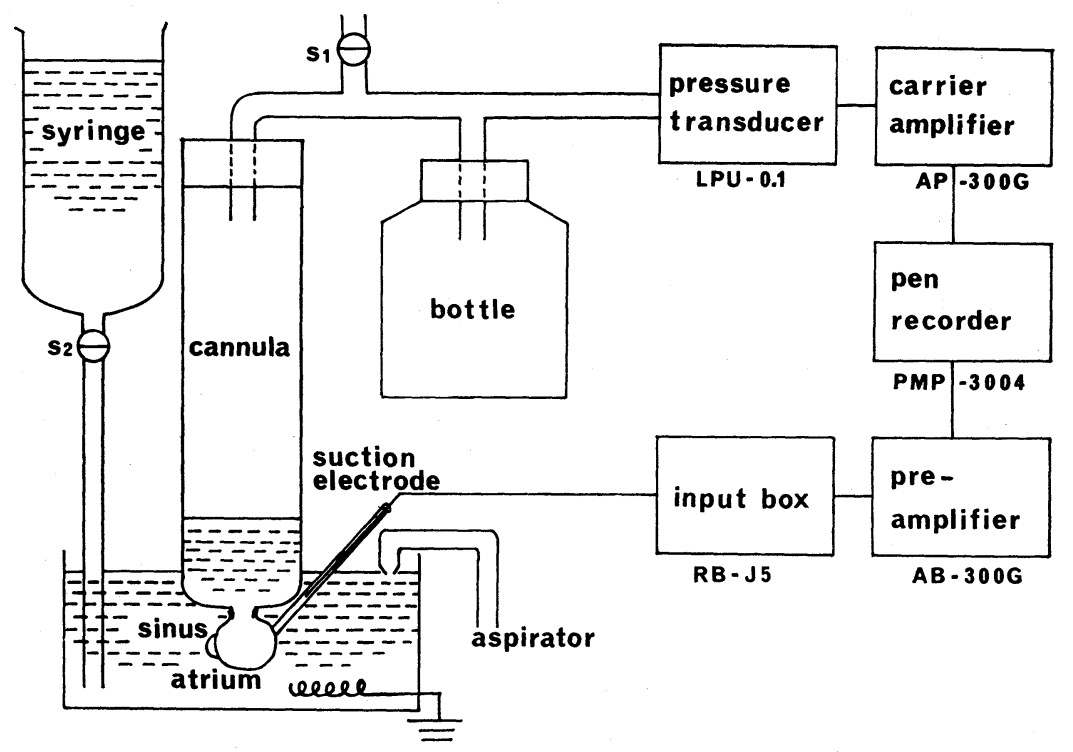

Fig. 1. Apparatus for simultaneous recording of electrical and mechanical activities of an everted sinus-atrium preparation.

Table 1. Composition of Ringer's solution (in mM).

\begin{tabular}{lrrr}
\hline & Normal R* & $\begin{array}{c}\text { Control R } \\
(\mathrm{Cl}-\mathrm{R})\end{array}$ & $\mathrm{SO}_{4}-\mathrm{R}$ \\
\hline $\mathrm{NaCl}$ & 110 & 90 & 0 \\
$\mathrm{Na}_{2} \mathrm{SO}_{4}$ & 0 & 0 & 45 \\
$\mathrm{KCl}$ & 2 & 2 & 0 \\
$\mathrm{~K}_{2} \mathrm{SO}_{4}$ & 0 & 0 & 1 \\
$\mathrm{CaCl}_{2}$ & 1 & 1 & 0 \\
$\mathrm{Ca}$ gluconate & 0 & 0 & 1 \\
$\mathrm{Glucose}_{\mathrm{Sucrose}}$ & 10 & 10 & 10 \\
$\mathrm{Tris} / \mathrm{HCl}^{* *}$ & 0 & 0 & 61 \\
$\mathrm{Tris} / \mathrm{H}_{2} \mathrm{SO}_{4}$ & 10 & 30 & 0 \\
$\mathrm{pH}$ & 0 & 0 & 30 \\
\hline
\end{tabular}

* R: Ringer's solution.

**Buffer solution for pH 10 Ringer's solution was glycine- $\mathrm{NaOH}$ instead of Tris-HCl.

filled with $3 \mathrm{M} \mathrm{KCl}$; a preamplifier, Nihon Kohden MZ-4; a cathode-ray oscilloscope, AVB-8; and a kymograph camera, PC-2B).

The composition of Ringer's solution is shown in Table 1. The Ringer's solution of various $\mathrm{pHs}(\mathrm{pH}$ 6-10) was obtained by adjusting the amount of $\mathrm{HCl}$ (Toa Electronics $\mathrm{pH}$ meter HM-6A). Cd-containing Ringer's solution was made by addition of a small amount of concentrated Cd solution to the 
Cd-free Ringer's solution of various pHs. No change in $\mathrm{pH}$ of the solution was observed by addition of $\mathrm{Cd}$.

All the experiments were carried out at room temperature $\left(20-24^{\circ} \mathrm{C}\right)$.

Quantitative analysis of $\mathrm{Cd}$ in atrial muscle was carried out on the following preparations. Epicardium of an excised atrium was removed with a fine forceps in order to eliminate a thick non-muscular component of the epicardium (HORIUCHI and HAYASHI, 1973). Cadmium of various concentrations was applied to the spontaneously beating atrium in Ringer's solution of either $\mathrm{pH} 6.5$ or $\mathrm{pH} 9.0$ for $3 \mathrm{~min}$. The atrium was blotted immediately with a filter paper, weighed, then ashed with a plasma reactor (Yamato PR-302) at about $100^{\circ} \mathrm{C}$ for $12 \mathrm{hr}$ $\left(\mathrm{O}_{2}\right.$ supply, $40 \mathrm{ml} / \mathrm{min}$; power, $\left.120 \mathrm{~W}\right)$. The ashed atrium was dissolved in $0.15 \mathrm{ml}$ of $0.5 \mathrm{~N} \mathrm{HCl}$, and the resulting solution was diluted with distilled water to make up to $10 \mathrm{ml}$. Its $\mathrm{Cd}$ concentration was determined by atomic absorption spectrophotometry (Hitachi 508 A) using a standard additional method.

\section{RESULTS}

\section{Effects of various pHs and Cd concentrations on contraction}

In the previous experiment on a bullfrog sinus-atrium preparation, it was shown that $\mathrm{Cd}$ of $13 \mu \mathrm{M}$ in normal Ringer's solution $(\mathrm{pH} 7.2)$ decreased the contractility of the cardiac muscle to almost half without an appreciable change in its membrane potential (HAYASHI and HoRIUCHI, 1971a). In the present experiment it was found that if the $\mathrm{pH}$ of the Ringer's solution was raised, this Cd effect was reduced. A typical example is shown in Fig. 2. First, in the

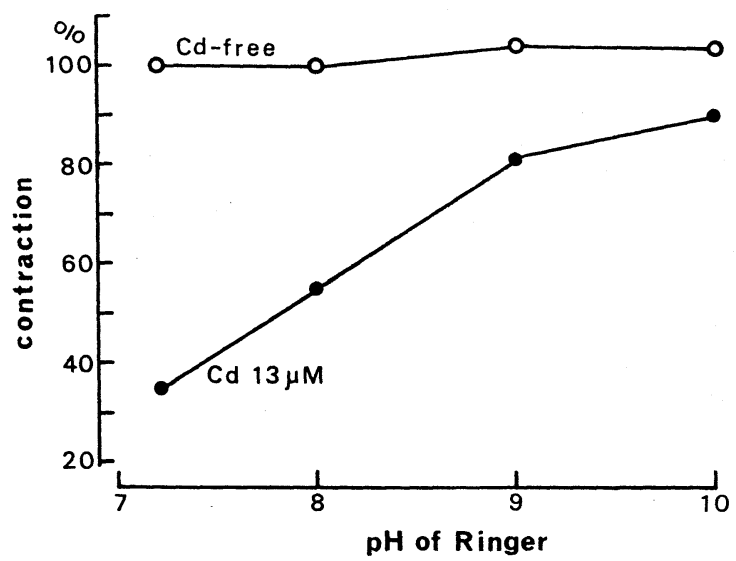

Fig. 2. Effects of various pHs on the contractility of atrial muscle in the presence or absence of $\mathrm{Cd}(13 \mu \mathrm{M})$. Contraction is expressed as a percentage of that in $\mathrm{pH} 7.2$ control Ringer's solution. 
pH 7.2 control Ringer's solution we started to measure cardiac output, which was the indicator of isotonic contraction, then we applied $13 \mu \mathrm{M} \mathrm{Cd}$ to the preparation by adding a small amount of concentrated $\mathrm{CdCl}_{2}$ into the perfusing solution. Recording was made $3 \mathrm{~min}$ after the application of $\mathrm{Cd}$, and the preparation was washed with $300-600 \mathrm{ml}$ (10-20 times the chamber volume) of the pH 7.2 control Ringer's solution. After such washing, the contractility was almost restored to the initial control value. The control Ringer's solution of a different $\mathrm{pH}$ was then tested, and so forth. All the data were standardized by contraction in the $\mathrm{pH} 7.2$ control Ringer's solution.

When the $\mathrm{pH}$ of the control Ringer's solution increased from 7.2 to 10.0, the contractility increased only slightly, i.e., to $104.6 \%$ in this case (contractility in the latter $\mathrm{pH}$ solution divided by that in the former).

On the other hand, the effects of $\mathrm{Cd}$ were dramatically altered as the $\mathrm{pH}$ of the external solution changed, i.e., Cd decreased the contractility to $34.4 \%$ of control in $\mathrm{pH} 7.2$ solution, but to only $90.6 \%$ in $\mathrm{pH} 10.0$ solution, in this case. The extent of the $13 \mu \mathrm{M}$ Cd-induced decrease in contractility varied from preparation to preparation, but $\mathrm{Cd}$ was always more effective in a lower $\mathrm{pH}$ solution than in a higher one (35-55\% of control in $\mathrm{pH} 7.2$ solution, and only $85-95 \%$ in $\mathrm{pH} 10.0$ solution).

The effects of various concentrations of $\mathrm{Cd}$ on the contractility of atrial muscle in sinus-atrium preparations in $\mathrm{pH} 9.0$ and $\mathrm{pH} 6.5$ Ringer's solution are shown in Fig. 3. Each measurement was made after the preparation had been washed out by a large amount of Ringer's solution, and all data were expressed as percentages of those before each application of $\mathrm{Cd}$. Both in the higher concentration of $\mathrm{Cd}$ and in the lower $\mathrm{pH}$ solution, the contractility

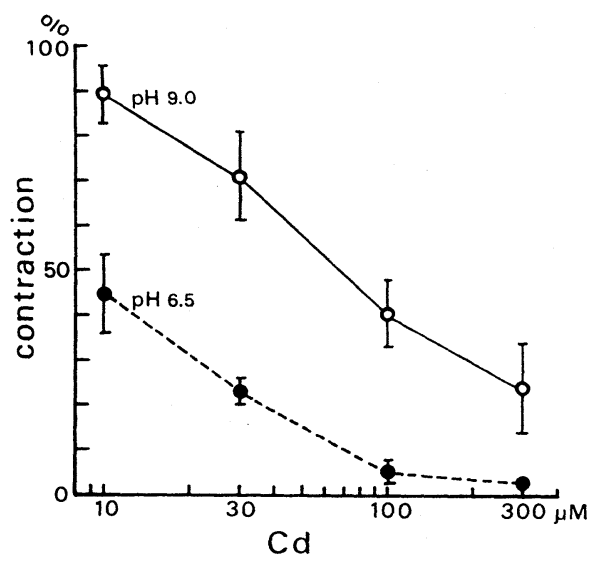

Fig. 3. Effects of various concentrations of $\mathrm{Cd}$ for $3 \mathrm{~min}$ on the contractility of atrial muscle in relation to $\mathrm{pH}(6.5$ and 9.0). The contraction is expressed as a percentage of that before each application of $\mathrm{Cd}$. Vertical bars represent standard error of means (5 cases). 
of atrial muscle was decreased; the contractility decreased to almost zero in $100 \mu \mathrm{M} \mathrm{Cd}-\mathrm{pH} 6.5$ Ringer's solution, but about $40 \%$ of control contraction remained in $100 \mu \mathrm{M} \mathrm{Cd}-\mathrm{pH} 9.0$ Ringer's solution. From another viewpoint, $100 \mu \mathrm{M} \mathrm{Cd}$ in $\mathrm{pH} 9.0$ brought about almost the same effect on contraction as one-tenth the $\mathrm{Cd}(10 \mu \mathrm{M})$ in a $\mathrm{pH} 6.5$ solution.

\section{Effects of $\mathrm{Cd}$ on the electrical activity in various $\mathrm{pH}$ solutions}

Figure 4 illustrates the effects of $13 \mu \mathrm{M} \mathrm{Cd}$ on the duration of action potential and the interval of spontaneous beat of everted sinus-atrium preparations in various $\mathrm{pH}$ Ringer's solutions. The action potential was obtained by using a suction electrode. The duration of the action potential was defined as the duration at the level of $10 \%$ of the amplitude of the action potential. All the data were standardized with those in $\mathrm{pH} 7.2$ control Ringer's solution. The extent of change in the action potential duration and the cardiac interval with change in the $\mathrm{pH}$ of the external solution varied between preparations. For the present purpose of investigating the $\mathrm{pH}$ dependency of the $\mathrm{Cd}$ effect on contraction, a preparation was selected whose duration and cardiac interval was hardly altered by $\mathrm{pH}$ change since changes in these parameters per se would affect the contractility. $\mathrm{Cd}$ increased both the interval and duration of the action potential very slightly in the whole range of $\mathrm{pH}$ (the difference was less than $10 \%$ of the control), but no $\mathrm{pH}$-dependent $\mathrm{Cd}$ effect was observed which was quite different from $\mathrm{Cd}$ effects on contraction.
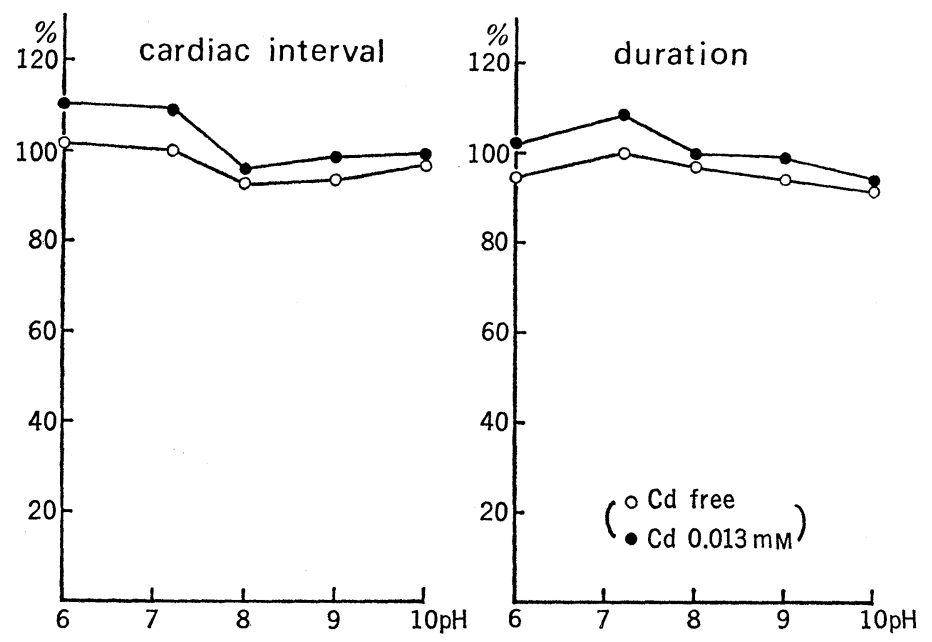

Fig. 4. Effects of various $\mathrm{pHs}$ on cardiac intervals and durations of action potential recorded by using a suction electrode with or without $\mathrm{Cd}(13 \mu \mathrm{m})$ for $3 \mathrm{~min}$. The cardiac interval and duration are expressed as percentages of those in $\mathrm{pH} 7.2$ control Ringer's solution. 

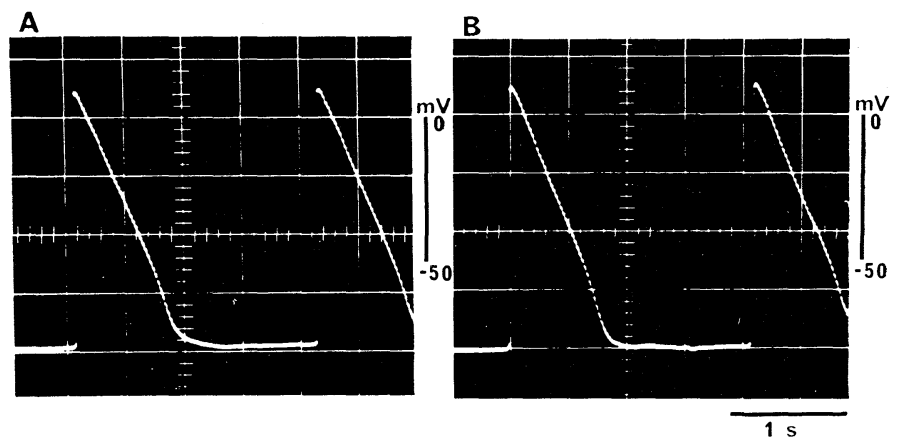

Fig. 5. Effects of $\mathrm{Cd}$ on the intracellular membrane potential of a spontaneously beating atrial muscle. A: membrane potential in control Ringer's solution of $\mathrm{pH} 6.5$ (Cdfree). B: that of atrium treated with $\mathrm{Cd}$ of $30 \mu \mathrm{M}$ for $3 \mathrm{~min}(\mathrm{pH} 6.5)$. Note no appreciable changes in resting or action potential were observed by application of $\mathrm{Cd}$.

The above-stated results obtained by a suction electrode were tested by using an intracellular microelectrode technique. The sinus-atrium preparation was fixed, with the endocardial face upward, on a cork plate. A typical example of a record obtained from an excised atrium with sinus is shown in Fig. 5. First, the action potential of a spontaneously beating atrium was recorded intracellularly in pH 6.5 control Ringer's solution (Fig. 5A). Then, this control solution was substituted by $30 \mu \mathrm{M} \mathrm{Cd}-\mathrm{pH} 6.5$ Ringer's solution. After the application of $\mathrm{Cd}$ for $3 \mathrm{~min}$ (namely, when the mechanical recording was made), the membrane potential was again recorded (Fig. 5B). $\mathrm{Cd}$ in $\mathrm{pH} 6.5$ Ringer's solution caused a very slight change in the spike amplitude, duration of action potential, resting potential and cardiac interval (102, 100, 104 and $101 \%$ respectively, in this case), while contractility under the binocular microscope had almost disappeared.

The results in $\mathrm{pH} 9.0$ Ringer's solution were similar to those in $\mathrm{pH} 6.5$ solution; i.e., $\mathrm{Cd}$ of $30 \mu \mathrm{M}$ for 3 min caused no appreciable change in the spike amplitude, duration of action potential, resting potential, or cardiac interval (the difference was less than $2 \%$ of the control) while contractility decreased slightly.

The parameters stated above were not greatly affected (less than $5 \%$ ) by simple alteration of the external $\mathrm{pH}$ of the control Ringer's solution from 6.5 to 9.0 .

\section{Influence of anion on $\mathrm{pH}$-dependent $\mathrm{Cd}$ effects}

Chloride ion is known as a carrier of ionic current during a cardiac action potential. Hence, the possibility was examined of whether the pH-dependent $\mathrm{Cd}$ effects on contraction were coupled with anion. This was tested by substituting $\mathrm{Cl}$ for $\mathrm{SO}_{4}$ which is thought to be an anion that does not permeate the cel- 

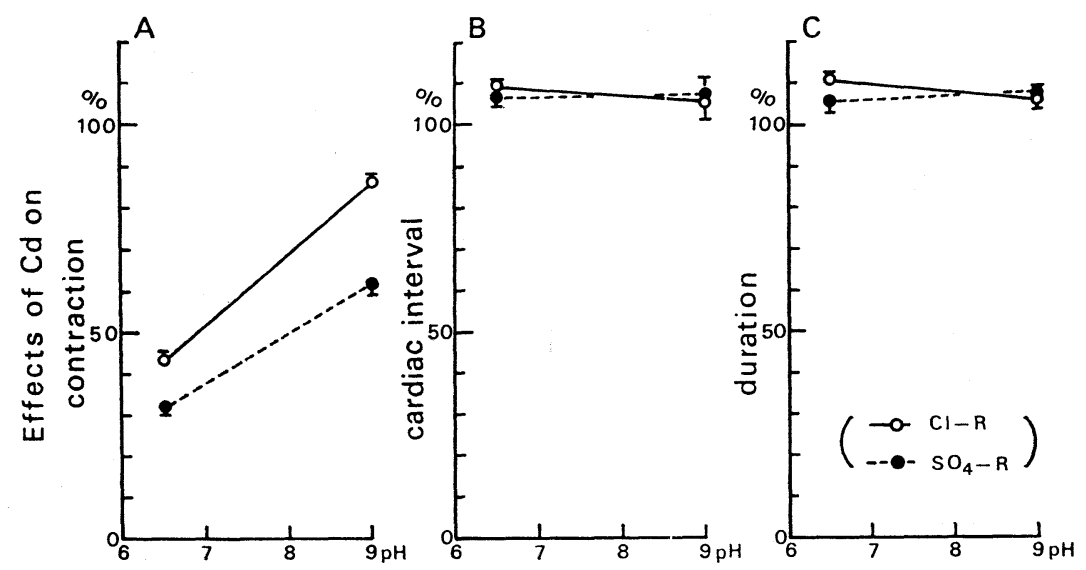

Fig. 6. Effects of $\mathrm{Cd}(13 \mu \mathrm{M}, 3 \mathrm{~min})$ on the contractility of atrial muscle (A), cardiac interval (B) and duration of action potential (C) in relation to $\mathrm{pH}$ and anion species $\left(\mathrm{Cl}\right.$ and $\left.\mathrm{SO}_{4}\right)$. Data are expressed as percentages of those before each application of $\mathrm{Cd}$.

lular membrane. The action potential was recorded by a suction electrode. Figure 6 illustrates the Cd effects (13 $\mu \mathrm{M}, 3 \mathrm{~min}$ ) on contraction (A), cardiac interval (B) and duration of action potential (C) in $\mathrm{Cl}$ - or $\mathrm{SO}_{4}$-Ringer's solution in relation to $\mathrm{pH}(6.5$ and 9.0). All the data were expressed as percentages of those prior to each application of $\mathrm{Cd}$. Although $\mathrm{Cd}$ did not cause changes in the cardiac interval or duration of action potential despite the alteration of anion species and $\mathrm{pH}$, a remarkable $\mathrm{pH}$ dependency of the $\mathrm{Cd}$ effect on contraction was observed in both $\mathrm{Cl}$ - and $\mathrm{SO}_{4}$-Ringer's solution; i.e., the lower the external $\mathrm{pH}$, the more pronounced the effects of $\mathrm{Cd}$ on contraction. The rate of $\mathrm{Cd}$-induced decrease in contractility in $\mathrm{SO}_{4}$-Ringer's solution was much greater than that in $\mathrm{Cl}-\mathrm{Ringer}$, irrespective of $\mathrm{pH}$.

pH-dependent antagonistic action of $\mathrm{Ca}$ against $\mathrm{Cd}$

Figure 7 shows an example of antagonism between $\mathrm{Cd}$ and $\mathrm{Ca}$ on contraction of atrial muscle of a spontaneously beating everted sinus-atrium preparation. $\mathrm{Cd}$ of $10 \mu \mathrm{M}$ in $\mathrm{pH} 6.5$ Ringer's solution brought about a marked decrease in contractility $\left(\mathrm{A}_{1}\right)$. When the contraction attained $50.7 \%$ of the control, 3 min after application of $\mathrm{Cd}$, a further $1.5 \mathrm{~mm} \mathrm{Ca}$ was added to the solution (final $\mathrm{Ca}$ concentration was $2.5 \mathrm{~mm}$ ). The contraction was restored to $88.6 \%$ of the control $2.5 \mathrm{~min}$ later $\left(\mathrm{A}_{2}\right)$. $\mathrm{Cd}$ of $10 \mu \mathrm{M}$ in $\mathrm{pH} 9.0$ Ringer's solution for 3 min slightly decreased the contraction of atrial muscle $(85.3 \%$ of the control) $\left(\mathrm{B}_{1}\right)$. A further addition of $0.3 \mathrm{~mm} \mathrm{Ca}$ (final $\mathrm{Ca}$ concentration was $1.3 \mathrm{~mm})$ almost restored the contraction $(91.1 \%$ of the control $)\left(B_{2}\right)$. The amount of $\mathrm{Ca}$, which was added to the solution for complete restoration of twitch 


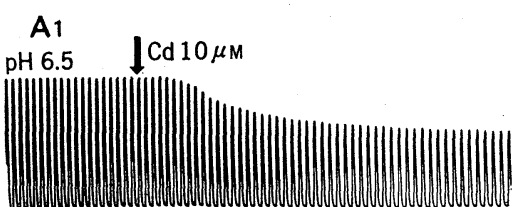

A2

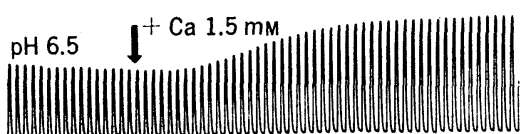

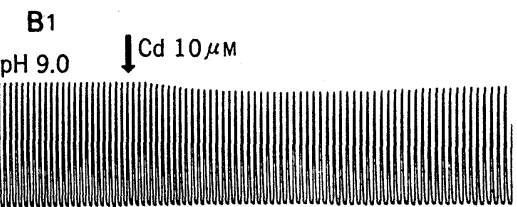

B2

$\mathrm{pH} 9.0 \quad \downarrow^{+} \mathrm{Ca} 0.3 \mathrm{~mm}$

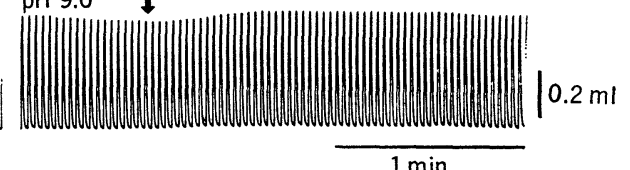

Fig. 7. Antagonistic action of $\mathrm{Ca}$ against $\mathrm{Cd}$ on the contractility of atrial muscle. $\mathrm{A}_{1}$ and $A_{2}$ : experiments in $\mathrm{pH} 6.5$ Ringer's solution. $B_{1}$ and $B_{2}$ : those in $\mathrm{pH} 9.0$ solution. Applications of $\mathrm{Cd}(10 \mu \mathrm{M})$ are indicated by downward arrows in $\mathrm{A}_{1}$ and $\mathrm{B}_{1}$. Additions of $\mathrm{Ca}$ to $\mathrm{Cd}$-Ringer ( $3 \mathrm{~min}$ after application of $\mathrm{Cd}$ ) are indicated by downward arrows in $\mathrm{A}_{2}$ and $\mathrm{B}_{2}$.

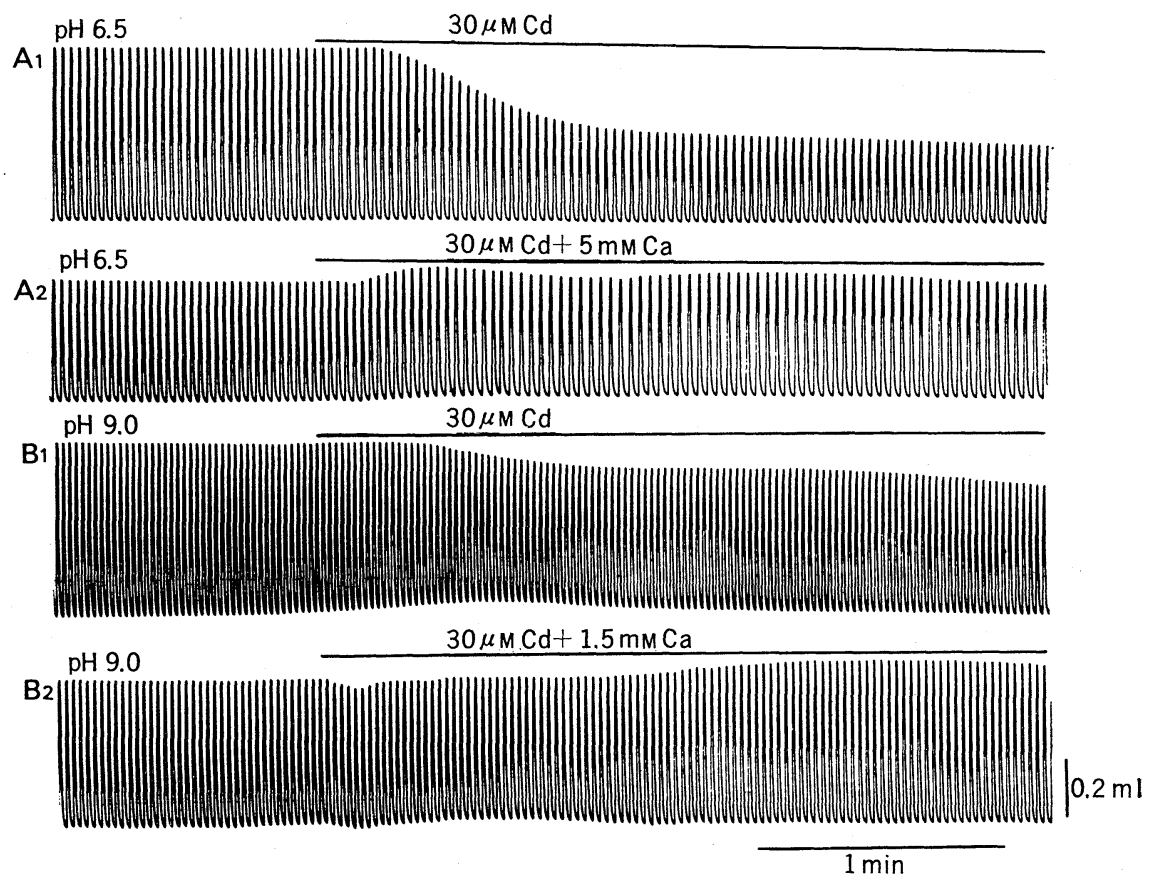

Fig. 8. Antagonistic action of $\mathrm{Ca}$ against $\mathrm{Cd}$ on the contractility of atrial muscle. $\mathrm{A}_{1}$ and $\mathrm{A}_{2}$ : experiments in $\mathrm{pH} 6.5$ Ringer's solution. $\mathrm{B}_{1}$ and $\mathrm{B}_{2}$ : those in $\mathrm{pH} 9.0$ solution. $\mathrm{Cd}$ of $30 \mu \mathrm{M}$ in $\mathrm{A}_{1}$ and $\mathrm{B}_{1}$, and $30 \mu \mathrm{M}$ Cd with high $\mathrm{Ca}$ in $\mathrm{A}_{2}$ and $\mathrm{B}_{2}$ were applied throughout the period indicated by horizontal bars. 
contraction, was larger in low $\mathrm{pH}$ Cd-Ringer's solution than in high $\mathrm{pH} \mathrm{Cd}$ solution ( $\mathrm{Cd}$ concentration was the same). The ratio of the added amount of $\mathrm{Ca}$ sufficient to counteract $\mathrm{Cd}$ in $\mathrm{pH} 6.5$ solution to that in $\mathrm{pH} 9.0$ solution was approximately $5(=1.5 \mathrm{~mm} / 0.3 \mathrm{~mm}$. The ratio was 2 for final Ca concentrations). A similar antagonism between $\mathrm{Cd}$ and $\mathrm{Ca}$ was also observed for a high concentration of $\mathrm{Cd}(30,100$ and $300 \mu \mathrm{M})$.

Antagonism between $\mathrm{Cd}$ and $\mathrm{Ca}$ on the contractility of cardiac muscle was examined in a different method. Figure 8 shows the effects of either Cd-Ringer's solution or $(\mathrm{Cd}+$ high $\mathrm{Ca})$-Ringer's solution on the contractility of atrial muscle of the everted sinus-atrium preparation. $\mathrm{Cd}$ of $30 \mu \mathrm{M}$ in $\mathrm{pH} 6.5$ Ringer's solution for 2.5 min markedly decreased the contractility $(45.7 \%$ of the control) $\left(\mathrm{A}_{1}\right)$. Despite containing the same concentration of $\mathrm{Cd}$, however, simultaneous application of $\mathrm{Cd}$ and high $\mathrm{Ca}$ ( $5 \mathrm{~mm} \mathrm{Ca}$ instead of $1 \mathrm{~mm} \mathrm{Ca}$ in control solution) in pH 6.5 Ringer's solution made no appreciable change in contractility $(96.8 \%$ of the control $3 \mathrm{~min}$ after application of $\mathrm{Cd}+$ high $\mathrm{Ca}$ mixture) $\left(\mathrm{A}_{2}\right)$. The same type of experiments were repeated in $\mathrm{pH} 9.0$ Ringer's solution $\left(\mathrm{B}_{1}\right.$ and $\left.\mathrm{B}_{2}\right)$. The amount of $\mathrm{Ca}$ which prevented the $\mathrm{Cd}$-induced decrease in contractility was much less in $\mathrm{pH} 9.0$ solution than in $\mathrm{pH} 6.5$ solution (the ratio of the latter to the former was approximately 3.3 in this case).

\section{Uptake of Cd into heart}

Various concentrations of $\mathrm{Cd}$ were administered to the atria in either $\mathrm{pH}$ 6.5 or pH 9.0 Ringer's solution for $3 \mathrm{~min}$. Then, the amount of Cd-uptake into cardiac tissue was measured by atomic absorption spectrophotometry. Figure 9 represents the relationship between the amount of $\mathrm{Cd}$ in the heart and the external $\mathrm{Cd}$ concentration in $\mathrm{pH} 6.5$ (closed circle) and $\mathrm{pH} 9.0$ (open circle)

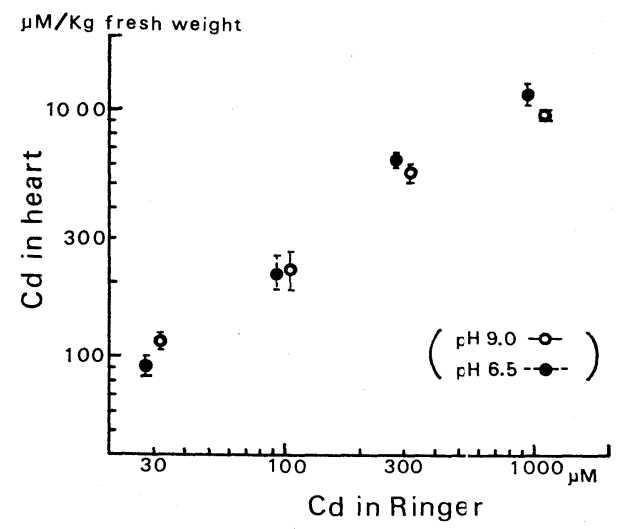

Fig. 9. Amount of Cd-uptake into atrium as a function of external $\mathrm{Cd}$ concentration in pH 6.5 (closed circle) and pH 9.0 (open circle) Ringer's solution (mean \pm SEM, 3 cases for each set of data except 6 cases for $100 \mu \mathrm{M}$ Cd-Ringer's solution). 
Ringer's solution. Let Cd-uptake into heart and Cd concentration in Ringer's solution be $y$ and $x$, respectively. Figure 9 shows that the higher " $y$ " is, the higher " $x$ " will be. The parameters of the experimental equation $\left(y=a \cdot x^{b}\right)$ are as follows: " $a$ " and " $b$ " are 7.34 and 0.75 in $\mathrm{pH} 6.5$ solution, and 13.1 and 0.63 in $\mathrm{pH} 9.0$ solution, respectively. The null hypothesis that these two experimental curves are equal cannot be discarded by a statistical method, because the slope of two linear regression lines in Fig. 9 are almost equal, and the vertical distance between these lines at the mean value of $\log x$ is almost zero. This signifies that no $\mathrm{pH}$ dependency was observed in the relationship between Cd-uptake in the heart and the external Cd concentration in Ringer's solution, even though contractility in low $\mathrm{pH}$ solution was markedly decreased by external $\mathrm{Cd}$ ( $c f$., Fig. 3). $\mathrm{Cd}$ in external Ringer's solution invades not only the interstitial fluid but also the cardiac tissue, because the concentration of $\mathrm{Cd}$ taken up into the heart is higher than that in the external solution (see DISCUSSION).

\section{DISCUSSION}

In this paper, we have reported for the first time that the negative inotropic effect of $\mathrm{Cd}$ on cardiac muscle in $\mathrm{pH} 7.2$ Ringer's solution was dramatically enhanced in acid Ringer's solution without appreciable change in action potential. A few investigators (KLEINFELd et al., 1955; TAKAHASHI et al., 1956; KLEINFELD and Stein, 1968; HAYASHI and Horiuchi, 1971a; Toda, 1973) have hitherto described the effects of $\mathrm{Cd}$ on the cardiac muscle, but none has tried to study the $\mathrm{Cd}$ effect in relation to $\mathrm{pH}$.

The negative inotropic effect on cardiac muscle in acid Ringer's solution per se has been studied by many investigators since GASKELL (1880) noticed this phenomenon. There are at least two possible mechanisms underlying the effect of acidosis: (1) acid Ringer causes a change in the action potential which might be due to a decrease in $\mathrm{Ca}$ influx, and (2) hydronium ion acts on sarcolemmal or intracellular $\mathrm{Ca}$ binding sites, thus decreasing the concentration of free $\mathrm{Ca}$ around the myofilaments upon contraction. Acid Ringer's solution caused the following change in the action potential: decrease in rate of rise of the action potential, decrease in slow $\mathrm{Na}$ and $\mathrm{Ca}$ current, and a variable change in the action potential duration (HeCHT and HUTTER, 1965; LoRKOVIĆ, 1966; Vaughan Williams and Whyte, 1967; van Bogaert and Carmeliet, 1972; WAdA and Goto, 1975; Poole-Wilson and LANGer, 1975; Chesnais et al., 1975), and an increase in heart rate due to change in $i_{\mathrm{K}_{2}}$ in alkaline solution (VAN BOGAERT et al., 1978). The reason that we did not observe the appreciable change in action potential with a change in the external $\mathrm{pH}$ is this: (1) We changed the $\mathrm{pH}$ of the external solution by $\mathrm{Tris} / \mathrm{HCl}$ buffer which caused a minor change in internal $\mathrm{pH}$, and the change in external $\mathrm{pH}$ alone was considered to be less effective on cardiac muscle (Lorković, 1966; Cingolani et al., 1970).

Vol. 29, No. 5, 1979 
In most experiments which caused the change in action potential in acid solution, $\mathrm{pH}$ was altered by changing the external $\mathrm{CO}_{2}$ concentration which in turn brought about a decrease in internal $\mathrm{pH}$. (2) Acidity-induced decrease in $\mathrm{Ca}$ current may be so small that seemingly no appreciable change was observed in the total shape of the action potential. KoHLHARDT et al. (1976) observed a decrease in $\mathrm{Ca}$ current with decrease in the external $\mathrm{pH}$, but they could not ascribe exclusively the reduction of contraction to the depression of $\mathrm{Ca}$ current because the extent and the time course of both were quite different.

Cadmium in Ringer's solution of normal pH caused a change in the action potential of cardiac muscle (KLEINFELD et al., 1955; TODA, 1973) and of snail neuron (KOSTYUK and KRISHTAL, 1977), but the application of a low concentration of $\mathrm{Cd}(10 \mu \mathrm{M})$ to a frog heart for a short time $(3 \mathrm{~min})$ brought about a decrease in contractility without an appreciable change in the action potential (HAYASHI and HorIUCHI, 1971a). The negative inotropic effects of $\mathrm{Cd}$ were ascribed to interference with $\mathrm{Ca}$ activity which altered the excitation-contraction coupling mechanism resulting in a decrease in contractility. In this experiment, cadmium in low pH Ringer's solution caused a marked decrease in contractility without any detectable change in action potential. The effect of $\mathrm{Cd}$ appeared rather rapidly: time constant of decrease in contractility was about $30 \mathrm{sec}$ in pH 6.5 solution ( $c f$. ., Fig. 1 in HorIUCHI and HAYASHI, 1978). In mammalian heart, the isolated sarcoplasmic reticulum (SR) from cardiac muscle binds $\mathrm{Ca}$ in low pH solution (NAKAMARU and SCHWARTZ, 1970), and thus decreases contractility. FABIATO and FABIATO (1978) pointed out that acidosis may exert the negative inotropic effect by modulating $\mathrm{Ca}$ sensitivity to both SR and myofilament. VAN BOGAERT et al. (1978) discussed the fact that alkaline solutions not only affected net negative surface charges on the outside but also, and to a greater extent, increased negative surface charges on the inside of the cell membrane. Hence, it may be possible that $\mathrm{Cd}$ in low $\mathrm{pH}$ solution may counteract $\mathrm{Ca}$ by competing for both these structures. However, it cannot be completely discounted that $\mathrm{Cd}$ in low $\mathrm{pH}$ solution impedes the trans-sarcolemmal $\mathrm{Ca}$ current which evokes the Ca-induced Ca release of SR (ENDo, 1977).

The anion of Ringer's solution might play a role in the $\mathrm{pH}$ dependency of the $\mathrm{Cd}$ effect for the following reasons: $\mathrm{Cl}$ permeability in barnacle muscle membrane increased as the external $\mathrm{pH}$ of the solution was lowered (HAGIWARA et al., 1968), and the cardiac action potential was believed to be associated in part with the $\mathrm{Cl}$ current (HutTer and Noble, 1961; LeNFANT and GoupIL, 1977). The above hypothesis was examined by substituting $\mathrm{Cl}$ in Ringer's solution for $\mathrm{SO}_{4}$ which was thought to be less penetrating than $\mathrm{Cl}$ (HAGIwARA et al., 1968; HAYASH et al., 1977). It was concluded that the hypothesis was not true because the tendency that the lowering of the $\mathrm{pH}$ makes $\mathrm{Cd}$ more effective was observed in both anion solutions. The twitch contraction of cardiac muscle was always smaller (almost half) in $\mathrm{SO}_{4}$-Ringer's solution than in $\mathrm{Cl}$ - 
Ringer's solution. This may be ascribed to the difference in $\mathrm{Ca}$ binding to the superficial membrane corresponding to the different anions (NAYLER, 1975).

The effect of $\mathrm{Cd}$ on the contractility of cardiac muscle was antagonized by excess $\mathrm{Ca}$. When $\mathrm{Ca}$ completely counteracted the $\mathrm{Cd}$ effect, the ratio of amount of $\mathrm{Ca}$ to that of $\mathrm{Cd}$ was $50-100$ in normal $\mathrm{pH}$ (KLEINFELD and STEIN, 1968; HAYASHI and Horiuchi, 1971a; ToDA, 1973). This $\mathrm{Ca} / \mathrm{Cd}$ ratio seemed to be different for various preparations. Cd-induced suppression of acetylcholinerelease from the vagal nerve terminal was also counteracted by excess $\mathrm{Ca}$, but the ratio was extremely high (1,000-2,000) (HAYASHI and TAKAYAMA, 1978). The lower the $\mathrm{pH}$, the higher the amount of $\mathrm{Ca}$ required to counteract $\mathrm{Cd}$ in cardiac muscle: the $\mathrm{Ca} / \mathrm{Cd}$ ratio was about 200 in $\mathrm{pH} 6.5$ solution, but the ratio was only about 50 in $\mathrm{pH} 9.0$ solution ( $c f$., Fig. 8). The difference in the $\mathrm{Ca} / \mathrm{Cd}$ ratio may be ascribed to the difference in affinity of $\mathrm{Cd}$ to the $\mathrm{Ca}$ binding sites, but we could not identify the $\mathrm{Ca}$ binding site even though the ultrastructure of the frog heart was described in detail (Staley and Benson, 1968). Reuben et al. (1971) observed that MgATP solution in the absence of Ca could elicit contraction of crayfish skinned muscle fiber. HAYASHI et al. (1972) found the non-competitive counteraction of ATP with $\mathrm{Cd}$ in cardiac muscle. This phenomenon should be investigated in more detail in relation to $\mathrm{pH}$.

The amount of $\mathrm{Cd}$ which was really taken up by the cardiac tissue was calculated from the data of Fig. 9. Assuming the intercellular space was $30 \%$ of the frog atrium ( $c f$. . HAJDU, 1953; GLITSCH, 1969) and that the concentration of $\mathrm{Cd}$ in the space was equal to that in the extracellular fluid, the real amount of $\mathrm{Cd}$ in the cardiac tissue was 4 times as much as that in the extracellular Ringer's solution (in the case of $30 \mu \mathrm{M}$ Cd-containing Ringer). This implied that the cardiac tissue actually took up the Cd by some mechanism not immediately obvious. The amount of Mn-uptake to the frog heart seemed to be smaller than that of Cd-uptake; Mn content in the heart was $1 / 20$ times as much as that in the extracellular Ringer's solution (CHAPMAN and Ellis, 1977). The higher the concentration of $\mathrm{Cd}$ in Ringer's solution, the more the amount of $\mathrm{Cd}$ taken up into the cardiac tissue. Though a marked $\mathrm{pH}$ dependency was observed in Cd-induced decrease in the contractility ( $c f$., Fig. 6), there was no difference in the amount of Cd-uptake whether the solution was acid or alkaline. This suggests that most of the amount of Cd-uptake is non-specific to the heart, and only a small fraction is essentially related to the $\mathrm{Ca}$ binding sites which are concerned with contraction. It remains to be determined what fraction or component of cardiac tissue combines most of the non-specific $\mathrm{Cd}$ or $\mathrm{Cd}$ specific to contraction.

The nature of the Ca-Cd interaction at the $\mathrm{Ca}$ binding sites may be inferred by the analogy of a chelating agent. The higher the stability constant of a chelating agent, the more acid the solution in which the formation of a metal chelating complex will occur. For example, the stability constant of EDTA 
for $\mathrm{Cd}$ and $\mathrm{Ca}$ are 16.5 and 10.6, respectively (SAKAguchi and Ueno, 1966); therefore, the amount of Cd-chelate complex is much larger than that of Cachelate complex in acid solution, which in turn may reveal the difference of divalent ion effects.

\section{REFERENCES}

Arita, A. and Hayashi, H. (1973) High input impedance and high CMR biological amplifier composed of operational amplifiers. Jpn. J. Med. Electron., 11: 124-127.

Chapman, R. A. and Ellis, D. (1977) Uptake and loss of manganese from perfused frog ventricles. J. Physiol. (Lond.), 272: 355-366.

Chesnais, J. M., Coraboeuf, E., Sauviat, M. P., and Vassas, J. M. (1975) Sensitivity to H, $\mathrm{Li}$ and $\mathrm{Mg}$ ions of the slow inward sodium current in frog atrial fibres. J. Mol. Cell. Cardiol., 7: 627-642.

Cingolani, H. E., Mattiazzi, A. R., Blesa, E. S., and Gonzalez, N. C. (1970) Contractility in isolated mammalian heart muscle after acid-base changes. Circ. Res., 26: 269-278.

Endo, M. (1977) Calcium release from the sarcoplasmic reticulum. Physiol. Rev., 57: 71-108.

Fabiato, A. and Fabiato, F. (1978) Effects of $\mathrm{pH}$ on the myofilaments and the sarcoplasmic reticulum of skinned cells from cardiac and skeleta! muscles. J. Physiol. (Lond.), 276: 233-255.

Gaskell, W. H. (1880) On the tonicity of the heart and blood vessels. J. Physiol. (Lond.), 3: 48-75.

Glitsch, H. G. (1969) Uber das Membranpotential des Meerschweinchenvorhofes nach Hypothermie. Pflügers Arch., 307: 29-46.

HAJDU, S. (1953) Mechanism of staircase and contracture in ventricular muscle. Am. J. Physiol., 174: 371-380.

Hagiwara, S., Gruener, R., Hayashi, H., Sakata, H., and Grinnell, A. D. (1968) Effect of external and internal $\mathrm{pH}$ changes on $\mathrm{K}$ and $\mathrm{Cl}$ conductances in the muscle fiber membrane of a giant barnacle. J. Gen. Physiol., 52: 773-792.

HaYASHI, H. and HoRIUCHI, E. (1971a) Effect of cadmium ion on the bullfrog heart. $J$. Physiol. Soc. Jpn., 33: 368-369.

HAYASHI, H. and HoRIUCHI, E. (1971b) Everted sinus-atrium preparation: A new method for simultaneous recording of the electrical and mechanical activity of the heart. Med. Biol., 83: 245-250 (in Japanese).

Hayashi, H., Horiuchi, E., and Takeda, M. (1972) Antagonistic action of ATP on the negative inotropic effect of $\mathrm{Cd}^{2+}$ in the frog heart. Med. Biol., 84: 243-248 (in Japanese).

Hayashi, H., TAKada, M., and Arita, A. (1977) Effects of cadmium on the active transport of sodium by the abdominal skin of a bullfrog (Rana catesbeiana). Jpn. J. Physiol., 27: $337-352$.

HAYASHI, H. and TAKAYAMA, K. (1978) Inhibitory effects of cadmium on the release of acetylcholine from cardiac nerve terminals. Jpn. J. Physiol., 28: 333-345.

Hecht, H. H. and Hutter, O. F. (1965) Action of pH on cardiac Purkinje fibres. In: Electrophysiology of the Heart, ed. by Taccardi, B. and Marchetti, G. Pergamon, Oxford, pp. 105-123.

Horiuchi, E. and Hayashi, H. (1973) Seasonal variation in the thickness of adipose tissue around the bullfrog heart. J. Nippon Med. Sch., 40: 72-75.

Horiuchi, E. and HaYashi, H. (1978) pH-dependent Cd effects on the contractility of the frog cardiac muscle. Med. Biol., 96: 125-129 (in Japanese).

Hutter, O. F. and Noble, D. (1961) Anion conductance of cardiac muscle. J. Physiol. 
(Lond.), $157:$ 335-350.

Kleinfeld, M. and Stein, E. (1968) Action of divalent cations on membrane potentials and contractility in rat atrium. Am. J. Physiol., 215: 593-599.

Kleinfeld, M., Greene, H., Stein, E., and Magin, J. (1955) Effect of the cadmium ion on the electrical and mechanical activity of the frog heart. Am. J. Physiol., 181: 35-38.

Kohlhardt, M., HaAp, K., and Figulla, H. R. (1976) Influence of low extracellular pH upon the $\mathrm{Ca}$ inward current and isometric contractile force in mammalian ventricular myocardium. Pflügers Arch., 366: 31-38.

Kostyuk, P. G. and Krishtal, O. A. (1977) Separation of sodium and calcium currents in the somatic membrane of mollusc neurones. J. Physiol. (Lond.), 270: 545-568.

LENFANT, J. and GoupIL, N. (1977) Effects of the replacement of chloride by methylsulphate on the membrane currents in frog atrial trabeculae. Pflügers Arch., 372: 121-129.

Lorković, H. (1966) Influence of changes in pH on the mechanical activity of cardiac muscle. Circ. Res., 19: 711-720.

Nakamaru, Y. and Schwartz, A. (1970) Possible control of intracellular calcium metabolism by $\left[\mathrm{H}^{+}\right]$: Sarcoplasmic reticulum of skeletal and cardiac muscle. Biochem. Biophys. Res. Commun., 41 : 830-836.

NAYLER, W. G. (1975) Some factors which influence the amount of calcium stored at the superficially located sites in cardiac muscle cells. In: Recent Advances in Studies on Cardiac Structure and Metabolism, Vol. 5, ed. by Fleckenstein, A. and Dhalla, S. University Park Press, Baltimore, pp. 73-79.

Poole-Wilson, P. A. and Langer, G. A. (1975) Effect of pH on ionic exchange and function in rat and rabbit myocardium. Am. J. Physiol., 229: 570-581.

Reuben, J. P., Brandt, P. W., Berman, M., and Grundfest, H. (1971) Regulation of tension in the skinned crayfish muscle fiber. I. Contraction and relaxation in the absence of $\mathrm{Ca}$ (pCa >9). J. Gen. Physiol., 57: 385-407.

Sakaguchi, T. and Ueno, K. (1966) Metal Chelate, Vol. II, Nankodo, p. 300, Tokyo (in Japanese).

Staley, N. A. and Benson, E. S. (1968) The ultrastructure of frog ventricular cardiac muscle and its relationship to mechanisms of excitation-contraction coupling. J. Cell. Biol., 38: 99-114.

Takahashi, H., Watanabe, K., Morita, N., and Tomikawa, T. (1956) Effects of some sulfhydryl reagents on the mechanical and electrical activity of the toad's heart. Jpn. J. Physiol., 6: 226-235.

ToDA, N. (1973) Influence of cadmium ions on the transmembrane potential and contractility of isolated rabbit left atria. J. Pharmacol. Exp. Ther., 186: 60-66.

van Bogaert, P. P. and Carmeliet, E. (1972) Sodium inactivation and $\mathrm{pH}$ in cardiac Purkyně-fibers. Arch. Int. Physiol. Biochim., 80: 833-835.

van Bogaert, P. P., Vereecke, J. S., and Carmeliet, E. (1978) The effect of raised pH on pacemaker activity and ionic currents in cardiac Purkinje fibers. Pflügers Arch., 375: 45-52.

Vaughan Williams, E. M. and Whyte, J. M. (1967) Chemosensitivity of cardiac muscle. J. Physiol. (Lond.), 189: 119-137.

WADA, Y. and Goto, M. (1975) Effects of $\mathrm{pH}$ on the processes of excitation-contraction coupling of bullfrog atrium. Jpn. J. Physiol., 25: 605-620.

Williamson, J. R., Woodrow, M. L., and Scarpa, A. (1975) Calcium binding to cardiac sarcolemma. In: Recent Advances in Studies on cardiac Structure and Metabolism, Vol. 5, ed. by Fleckenstein, A. and Dhalla, N. S. University Park Press, Baltimore, pp. 61-71.

Vol. 29, No. 5, 1979 